\title{
Honrar o passado, olhar para o futuro
}

Rev Port Imunoalergologia 202I;29 (I): I I-I 2

Mariana Couto

Centro de Alergia, Hospital CUF Descobertas, Lisboa

A Revista Portuguesa de Imunoalergologia (RPIA) celebra os seus 30 anos! Em 1991 davam-se os primeiros passos na preparação e organização desta Revista que tem divulgado ao longo de todos estes anos a produção científica nacional, primando pelo elevado nível de qualidade científica. Ao longo destas três décadas, a RPIA foi sofrendo remodelação de imagem e design, foram sendo adicionadas mais secções para melhor ir de encontro às expectativas dos autores e foi-se adaptando à evolução tecnológica com o seu atual formato eletrónico, mas sem nunca perder a sua identidade.

Cabe, antes de mais, expressar um profundo agradecimento a todos os Editores que me antecederam e que ao longo dos anos com a sua dedicação mantiveram esta identidade da RPIA e a promoveram ao lugar de destaque que hoje ocupa no panorama da divulgação da investigação imunoalergológica em língua portuguesa (a RPIA é a única revista da especialidade em língua nativa), que muito nos orgulha. Neste número, temos a publicação do primeiro artigo na secção ASBAI, transparecendo a colaboração entre países e enaltecendo a excelência da nossa Revista, que começa a ser procurada por cada vez mais colegas para a submissão dos seus trabalhos.

A crescente qualidade e a quantidade dos artigos que temos vindo a publicar aos longo dos anos é fruto da excelência da investigação científica nacional e nesse sentido não poderia esquecer de deixar também uma nota de reconhecimento aos Autores que regularmente nos confiam os seus trabalhos, assim contribuindo para uma melhoria da prática clínica na área de Alergologia e Imunologia. Celebramos este aniversário com a criação de mais um prémio RPIA para os artigos em formato de caso-clínico, que desta feita se separam dos artigos de revisão merecendo o seu destaque próprio. Este formato entra já em vigor e os vencedores dos três prémios RPIA 202I ( . $^{\circ}$ Prémio - para o melhor artigo original, sob a forma de inscrição, viagem e alojamento, para congresso internacional na área da Imunoalergologia, até ao valor de 1500 euros; 2 . $^{\circ}$ Prémio - para o melhor artigo de revisão, sob a forma de inscrição, viagem e alojamento, para congresso nacional na área da Imunoalergologia, até ao valor de 750 euros; 3 . Prémio $^{\circ}$ - para o melhor artigo caso clínico, sob a forma de inscrição, viagem e alojamento, para congresso nacional na área da Imunoalergologia, até ao valor de 750 euros) serão anunciados na Reunião da Primavera.

Este trajeto não teria sido possível sem a imprescindível colaboração dos Revisores a quem solicitamos a avaliação dos trabalhos propostos para publicação, e que abnegadamente número após número contribuem com o seu tempo e expertise clínica na revisão crítica e rigorosa dos manuscritos submetidos, que muito agradecemos. 
Considerando a constante necessidade de mais revisores disponíveis para que possamos diminuir os tempos de decisão das submissões, planeamos este ano, em articulação a direção da SPAIC, desenvolver um curso dedicado a técnicas de peer-review, seguido de um programa de mentoria que permitirá melhorar as competências de revisão científica.
Para este ano, de forma a celebrar as três décadas de evolução, a RPIA irá ver renovada a sua imagem, conservando a qualidade de conteúdo. Contamos com todos vós para seguirmos juntos com foco e compromisso de robustecer a nossa Revista!

Mariana Couto Editor da RPIA 